\title{
Identification of Streptococcus parasanguinis DNA contamination in human buccal DNA samples
}

\author{
Istiak Mahfuz', Wei Cheng ${ }^{2,3,4}$ and Stefan J White ${ }^{1 *}$
}

\begin{abstract}
Background: The use of buccal swabs in clinical and scientific studies is a very popular method of collecting DNA, due to its non-invasive nature of collection. However, contamination of the DNA sample may interfere with analysis.

Findings: Here we report the finding of Streptococcus parasanguinis bacterial DNA contamination in human buccal DNA samples, which led to preferential amplification of bacterial sequence with PCR primers designed against human sequence.

Conclusion: Contamination of buccal-derived DNA with bacterial DNA can be significant, and may influence downstream genetic analysis. One needs to be aware of possible bacterial contamination when interpreting abnormal findings following PCR amplification of buccal swab DNA samples.
\end{abstract}

\section{Findings}

Buccal swabs are a popular, inexpensive and noninvasive method of collecting DNA samples. It is a convenient procedure for collecting DNA from geographically isolated populations for larger cohort studies [1], and has the advantage of avoiding the stressful process of venepuncture. When using buccal swab DNA, sampling or processing considerations may be important for obtaining optimal results [2]. If buccal swabs are not collected and/or handled properly, potential complications may occur during subsequent analysis [3]. Problems that can affect the interpretation include contamination, degradation, and insufficient yield [4-6]. Here we report a significant Streptococcus parasanguinis DNA contamination in human buccal-derived DNA. This bacteria is the most abundant microorganism in the mouth, and a primary colonizer of human tooth surfaces $[7,8]$ that plays an important role in dental plaque formation $[9,10]$.

Contamination was detected during mutation screening of the Desmoplakin (DSP) gene in buccal DNA of Bladder Exstrophy Epispadias Complex (BEEC) patients. Use of samples for research was approved by the Research Ethics Committee of Royal Children's

\footnotetext{
* Correspondence: stefan.white@monash.edu

${ }^{1}$ Centre for Genetic Diseases, Monash Institute of Medical Research, Monash University, 27-31 Wright Street, Clayton 3168, VIC, Australia

Full list of author information is available at the end of the article
}

Hospital (Approval Number\# HREC28140A), Melbourne, Australia. Informed consent was also obtained from the patients or parents/guardians. The intention was to screen DSP exon 4 for potential sequence variants using High Resolution Melting (HRM) and Sanger Sequencing. For this, we designed exon-specific forward (5' CTGTTTTCCTGCAGTGGTT 3') and reverse (5' TGGCCTGCACAGGTTTG 3') primers, predicted to generate a 254 bp product. HRM was performed on 22 samples as previously described [11]. Five samples gave aberrant curves with HRM (Figure 1), and agarose gel analysis showed the presence of two bands in matching samples (Figure 2). Sanger sequence analysis showed that the $153 \mathrm{bp}$ fragment did not align with any human sequence. Alignment with other organisms showed 98\% identity with Streptococcus parasanguinis plasmid pFW213 [GenBank:EU685104.1] (Figure 3).

To our knowledge, there have been no previous reports of Streptococcus parasanguinis contamination affecting genetic analysis of buccal swab DNA. It is not unexpected to have Streptococcal DNA contamination in DNA from a human buccal swab, due to the high abundance in oral microflora [12,13]. In addition, when a buccal sample is collected, researchers generally do not enquire whether there is any oral disease. This might influence the quality of DNA isolated from buccal swabs. Under such 


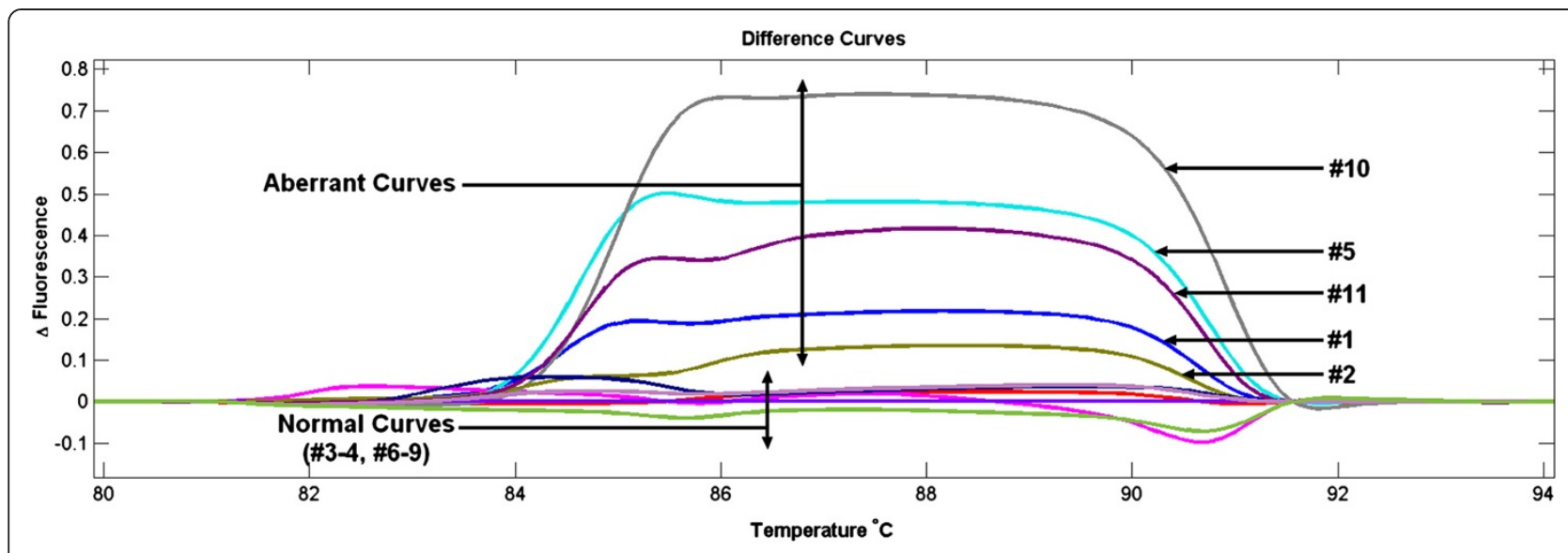

Figure 1 High Resolution Melt (HRM) analysis of PCR products from human buccal-derived DNA samples. The aberrant HRM curves are due to contamination with Streptococcus parasanguinis DNA.

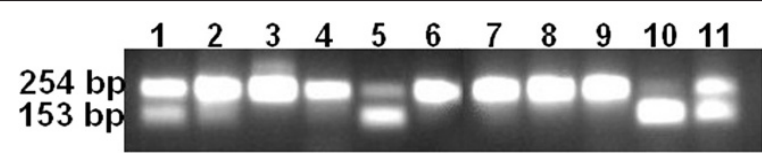

Figure $2 \mathrm{Gel}$ electrophoresis of the PCR products shown in Figure 1. The expected product from the human DNA is 254 bp, with the $153 \mathrm{bp}$ product matching Streptococcus parasanguinis DNA.

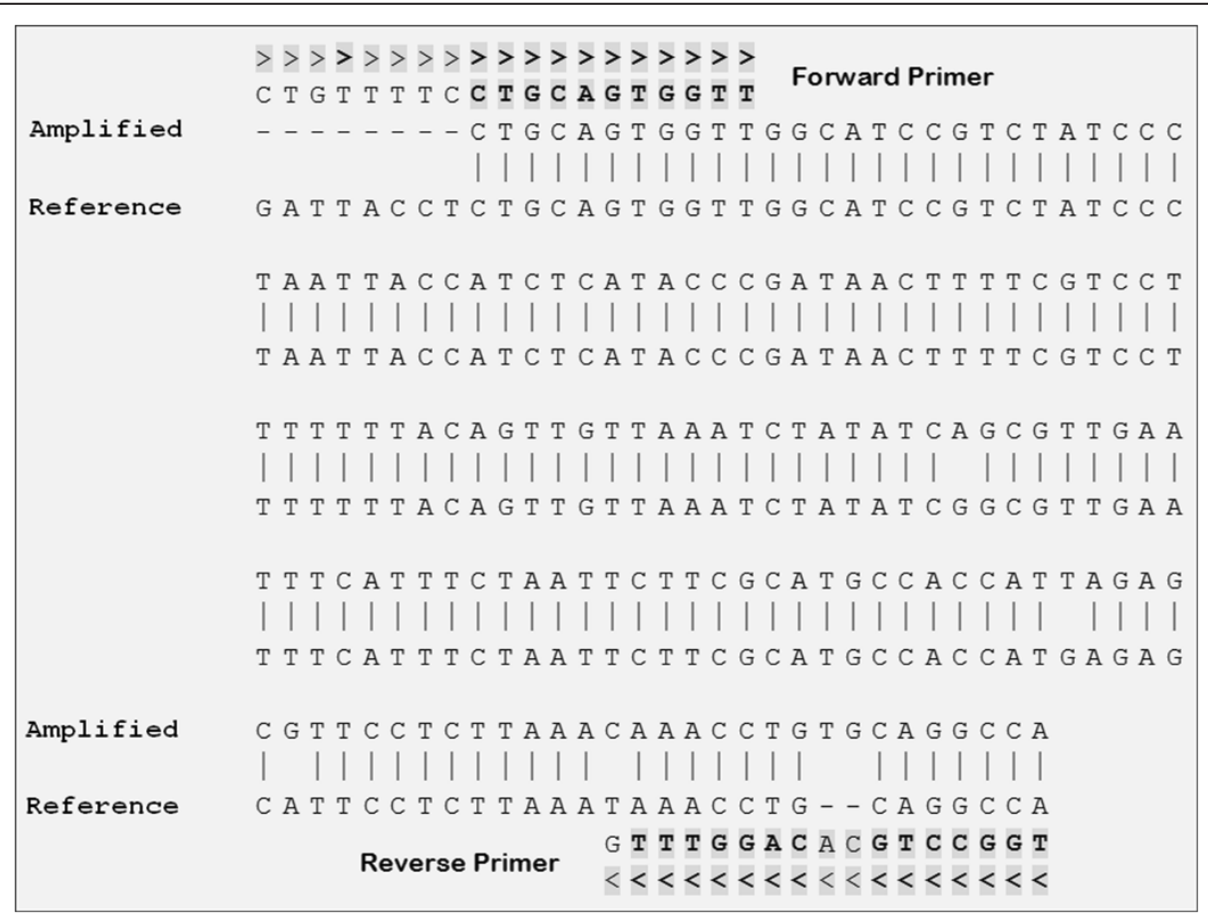

Figure 3 Alignment of the $153 \mathrm{bp} \mathrm{PCR} \mathrm{product} \mathrm{with} \mathrm{the} \mathrm{Streptococcus} \mathrm{parasanguinis} \mathrm{plasmid} \mathrm{pFW213} \mathrm{reference} \mathrm{sequence.} \mathrm{The} \mathrm{sequences}$ corresponding to the PCR primers are indicated in bold. 
circumstances, a blood sample may be a preferable method for obtaining DNA. A comparison of bloodand buccal-derived DNA from a Danish nurse cohort has previously been reported. 100\% of the blood-derived DNA samples could be genotyped or PCR amplified, whereas only $23 \%$ of the DNA samples from mouth swabs could be PCR amplified and none of the swab-derived DNA samples could be genotyped [14].

Our finding demonstrates that bacterial contamination may be a significant contributor to the total amount of DNA isolated from a buccal swab, and may explain why an apparently sufficient quantity of high quality DNA does not perform as expected in human-specific PCR amplifications.

\section{Competing interests}

The authors declare that they have no competing interests.

\section{Authors' contributions}

IM performed the molecular analysis and drafted the manuscript. WC helped in coordination and drafting of the manuscript. SW conceived of the study, participated in its design and coordination and drafted the manuscript. All authors read and approved the final manuscript.

\section{Authors' information}

Wei Cheng and Stefan J White: Joint senior authors.

\section{Acknowledgements}

We are grateful to Royal Children Hospital, Melbourne, Sick Kids, Toronto and Hostal Universitario La Paz, Madrid for providing the DNA samples. Research in the authors' laboratories is supported by the Jack Brockhoff Foundation, the Helen Macpherson Smith Trust, the Marian and E. H. Flack Trust, and Monash University. MIMR receives funding from the Victorian Government's Operational Infrastructure Support Program. IM is supported by a Monash Graduate Scholarship (MGS) and Faculty of Medicine, Nursing and Health Science International Postgraduate Scholarship (MIPS).

\section{Author details}

${ }^{1}$ Centre for Genetic Diseases, Monash Institute of Medical Research, Monash University, 27-31 Wright Street, Clayton 3168, VIC, Australia. ${ }^{2}$ Department of Paediatrics, Southern Medical School, Faculty of Medicine, Nursing and Health Sciences, Monash University, Melbourne, Australia. ${ }^{3}$ Department of Surgery, Southern Medical School, Faculty of Medicine, Nursing and Health Sciences, Monash University, Melbourne, Australia. ${ }^{4}$ Department of Surgery, Beijing United Family Hospital, Beijing, China.

Received: 7 May 2013 Accepted: 14 November 2013

Published: 22 November 2013

\section{References}

1. Freeman B, Powell J, Ball D, Hill L, Craig I, Plomin R: DNA by mail: an inexpensive and noninvasive method for collecting DNA samples from widely dispersed populations. Behav Genet 1997, 27(3):251-257.

2. Walker AH, Najarian D, White DL, Jaffe JF, Kanetsky PA, Rebbeck TR: Collection of genomic DNA by buccal swabs for polymerase chain reaction-based biomarker assays. Environ Health Perspect 1999, 107(7):517-520.

3. Collecting a Buccal Swab - An Art or a Cinch? http://www.hitdna.com/ images/PDFs/publications/Taking a Buccal Swab.pdf.

4. Beckett SM, Laughton SJ, Pozza LD, McCowage GB, Marshall G, Cohn RJ, Milne E, Ashton L: Buccal swabs and treated cards: methodological considerations for molecular epidemiologic studies examining pediatric populations. Am J Epidemiol 2008, 167(10):1260-1267.

5. Walsh DJ, Corey AC, Cotton RW, Forman L, Herrin GL Jr, Word CJ, Garner DD: Isolation of deoxyribonucleic acid (DNA) from saliva and forensic science samples containing saliva. J Forensic Sci 1992, 37(2):387-395.
6. Zayats T, Young TL, Mackey DA, Malecaze F, Calvas P, Guggenheim JA: Quality of DNA extracted from mouthwashes. PLoS One 2009, 4(7):e6165.

7. Tinanoff N, Gross A, Brady JM: Development of plaque on enamel. Parallel investigations. J Periodontal Res 1976, 11(4):197-209.

8. Socransky SS, Manganiello AD, Propas D, Oram V, van Houte J: Bacteriological studies of developing supragingival dental plaque. J Periodontal Res 1977, 12(2):90-106.

9. Carlsson J, Grahnen H, Jonsson G, Wikner S: Establishment of Streptococcus sanguis in the mouths of infants. Arch Oral Biol 1970, 15(12):1143-1148.

10. Jenkinson HF, Lamont RJ: Streptococcal adhesion and colonization. Crit Rev Oral Biol Med 1997, 8(2):175-200.

11. de Boer CM, Eini R, Gillis AM, Stoop H, Looijenga LH, White SJ: DICER1 RNase Illb domain mutations are infrequent in testicular germ cell tumours. BMC Res Notes 2012, 5:569.

12. The Human Microbiome Project Consortium: Structure, function and diversity of the healthy human microbiome. Nature 2012, 486(7402):207-214.

13. Rudney JD, Chen R, Zhang G: Streptococci dominate the diverse flora within buccal cells. J Dent Res 2005, 84(12):1165-1171.

14. Hansen TV, Simonsen MK, Nielsen FC, Hundrup YA: Collection of blood, saliva, and buccal cell samples in a pilot study on the Danish nurse cohort: comparison of the response rate and quality of genomic DNA. Cancer Epidemiol Biomarkers Prev 2007, 16(10):2072-2076.

doi:10.1186/1756-0500-6-481

Cite this article as: Mahfuz et al:: Identification of Streptococcus parasanguinis DNA contamination in human buccal DNA samples. BMC Research Notes 2013 6:481.

\section{Submit your next manuscript to BioMed Central and take full advantage of:}

- Convenient online submission

- Thorough peer review

- No space constraints or color figure charges

- Immediate publication on acceptance

- Inclusion in PubMed, CAS, Scopus and Google Scholar

- Research which is freely available for redistribution 